\title{
A comparison of Norwegian and Spanish L1 acquisition of possessive constructions
}

\author{
Antonio Fábregas ${ }^{1}$, Merete Anderssen ${ }^{1} \&$ Marit Westergaard $^{1,2}$ \\ ${ }^{1}$ UiT -The Arctic University of Norway, ${ }^{2}$ NTNU Norwegian University of Science \\ and Technology
}

\begin{abstract}
In language acquisition studies, there is a recurring debate regarding how to account for non-target-consistent utterances produced by young children. Anderssen \& Westergaard (2010) study the acquisition of Norwegian possessives, which may be pre- or postnominal, and find that children overuse prenominal possessives, even though they are considerably less frequent than postnominal ones in the input. The current study investigates Spanish possessive structures, which may also appear with two word orders, and finds that postnominal possessives are occasionally overused by young children, even though they are extremely low in frequency $(3 \%)$. In this article, we discuss two possible explanations for the non-target-consistent behavior of Norwegian and Spanish children, related to economy of syntactic movement and the nature of the possessives themselves in terms of strong/weak pronouns or clitics.
\end{abstract}

Keywords: possessives, acquisition, Spanish, Norwegian, frequency, complexity, strong/weak pronouns, clitics, economy

This is a post-print version reflecting changes made in the peer review and editing process, but it is not the publisher's PDF. This article appeared as:

Fabregás, Antonio, Merete Anderssen \& Marit Westergaard. 2019. Complexity and word order: a comparison of Norwegian and Spanish L1 acquisition of possessive constructions. Journal of Comparative Germanic Linguistics. Available here.

When citing, please use the page numbers given there. The publisher should be contacted for permission to re-use or reprint the material in any form. 


\section{Introduction}

Norwegian and Spanish, although typologically different languages, both allow possessive determiners to be either pre- or postnominal, as illustrated in (1a-d).
a. su libro
b. hans bok
his book
his book
b. un libro suyo
d. boka hans
a book his
book.DEF his

In this study, we compare the acquisition of possessive word order in Norwegian (investigated in Anderssen \& Westergaard 2010) to Spanish child data from several CHILDES corpora. Anderssen \& Westergaard (2010) show that Norwegian children have a different distribution of pre- and postnominal possessives compared to adult speakers of Norwegian. The children overuse prenominal possessives, even though these only represent $25 \%$ of the possessives they are exposed to in the input. This would be problematic in terms of a purely frequentist approach to language acquisition. In the current study, we show that children acquiring Spanish produce both word orders from early on. However, the children exhibit occasional non-targetconsistent use of postnominal possessives, which are extremely infrequent in Spanish, representing only $3 \%$ of possessives occurring with a noun. In the current paper, we present the Spanish data against the backdrop of Anderssen \& Westergaard's (2010) study and discuss two possible explanations for the unexpected overuse of prenominal possessives in Norwegian and postnominal possessives in Spanish.

\section{Norwegian and Spanish possessives in the adult language}

As mentioned above, possessives in Norwegian appear with two word orders, i.e. with the possessor either preceding or following the noun, as shown in (2). Note that the noun must appear with the definite suffix in the postnominal possessor construction.
a. mitt barn
my child
b. barn-et mitt
child-DEF my
'My child.' 
Spanish possessives may also occupy two positions relative to the head noun, but under more restricted conditions, as we shall see. Note that the two positions also require two different forms of the possessive, a short form in prenominal position (3a) and a long form in postnominal position (3b). The long form is also used when a possessive appears in isolation.
a. su hijo
his son
'His son.'
b. un hijo suyo

a son his

'His son/A son of his.'

In what follows we provide an overview of the empirical differences in the adult language between the two languages with respect to the position of the possessive.

\subsection{Information structure and definiteness}

In Norwegian, this word order variation is almost exclusively dependent on information structure, with the prenominal possessive normally receiving a contrastive interpretation, while the postnominal possessor construction is neutral (see e.g. Lødrup 2011, 2012). The difference in interpretation between the two word orders is illustrated by the example in (4), where a mother is talking about her daughter (Anderssen \& Westergaard 2010: 2580).

$$
\begin{aligned}
& \text { MOT: ja den derre jabba hennes den går i ett sett. } \\
& \text { yes that there mouth.DEF her it goes in one set } \\
& \text { 'Yes, that mouth of hers, it moves non-stop.' } \\
& \text { MOT: } æ \text { hørte hennes stemme over alle de andre når ækom.... } \\
& \text { I heard her voice over all the other when I came } \\
& \text { 'I heard her voice above all the others when I came (to pick her up).' }
\end{aligned}
$$

(Ann.05) 
In the first utterance, the mother is talking about her daughter's mouth moving nonstop and there is no special emphasis on the possessor (the possessive relationship is parenthetical). In this context, the postnominal possessive is used. In the second utterance, the mother contrasts her daughter's voice with that of the other children, and as a result the prenominal possessive is used. This difference in interpretation is also clear from the distribution of stress in the two word orders; in prenominal possessives, prominence is on the possessor, while in postnominal possessives, the noun receives prosodic prominence.

In contrast, the difference between the prenominal and the postnominal possessive in Spanish is only partially dependent on information structure. One of the orders is associated with contrastive focus as well, but it is the definite or indefinite nature of the DP that plays a bigger role in determining the position of the possessor. The distribution of the two possessives in Spanish spoken language has been discussed in a number of descriptive and theoretical works (Brucart 1994, Picallo \& Rigau 1999, Moreno de Alba 2001, Ihsane 2003, Ticio 2003, Huerta Flores 2009, RAE \& ASALE 2009: §18.3, Roca 2009, Eguren 2015, among others). The main generalisation is that the postnominal possessive in combination with an overt noun is used when the DP is not definite (5a) or when the NP is not headed by any (overt) determiner (5b), as the prenominal possessive forces a definite reading of the noun.

a. $\quad$ Es un amigo mío.

is a friend my

'He is a friend of mine.'

b. Es amigo mío.

is friend my

'He is a friend of mine.'

There is one case where the postnominal possessives can occur inside a definite DP (Picallo \& Rigau 1999). With third person possessives, it is possible to have the sequence $\mathrm{D}^{\text {def }} \mathrm{N}$ Poss, provided that the possessor is given contrastive exhaustive focus. Out of the blue, (6) is not a natural utterance in Spanish. However, with contrastive focus on the possessor, the sentence becomes acceptable, i.e. in a context where there are several books, each one of them belonging to only one person and we 
want to claim that the book in question belongs to her and to nobody else. Note that if one possessive position is associated with focus in Spanish, it is the postnominal one. This is the opposite of Norwegian, where the prenominal possessive is always contrastive in most varieties of the spoken language.

\#Este es el libro suyo.

this is the book her

In (European) Spanish, $1^{\text {st }}$ and $2^{\text {nd }}$ person possessives are ungrammatical in postnominal position with definite noun constituents (Brucart 1994). Utterances such as (7) are always judged by speakers as degraded in comparison to (8), even if contrastive focus is assigned to the possessor.

(7) a. ??/*Este es el coche mío. this is the car my

b. *Vine con la novia mía. I.arrived with the girlfriend my

(8) a. Este es mi coche. this is my car

b. Vine con mi novia. I.arrived with my girlfriend

To summarise, in Norwegian, the two word orders are dependent on information structure; the prenominal possessive is closely associated with contrastive focus, while the postnominal possessive is used when the possessive relationship is backgrounded. In Spanish a postnominal possessive is normally not acceptable inside a definite DP. A contrastive focus interpretation can save the postnominal possessive in such contexts, but never if it is $1^{\text {st }}$ or $2^{\text {nd }}$ person. Thus, the contrast between the two word orders in Spanish depends to a greater extent on the internal features of the possessive.

\subsection{Frequencies}

The corpus of adult Norwegian investigated by Anderssen \& Westergaard (2010) shows a distribution of approximately $75 \%$ for the postnominal order, while $25 \%$ of 
possessives are prenominal. This distribution is confirmed by data from 166 adult speakers in the NoTa-corpus of spoken Oslo Norwegian, with 73\% (1883/2583) of possessives being postnominal (Westergaard \& Anderssen 2015).

With respect to the distribution of the two word orders in Spanish, an examination of the spoken texts of the CREA corpus reveals that postnominal possessives are extremely infrequent compared to their prenominal counterparts. The CREA corpus, hosted by the Real Academia Española, is a corpus of contemporary Spanish (last 25 years) that contains 350 million words, and, to the best of our knowledge, this is the largest available corpus that contains sections for spoken language. The corpus does not allow for grammatical searches, so the data had to be classified manually in order to exclude possessives occurring in isolation. ${ }^{1}$ Only texts tagged as oral and European Spanish in CREA were taken into account. In total the searches yielded 22498 examples of the short form and 1895 long forms. However, the majority of the latter type $(62 \%, 1176 / 1895)$ occurred in isolation. This resulted in a total of 719 postnominal possessives with overt nouns (against almost 22,500 instances of the prenominal ones), making up only $3 \%$ of the total. This information is summarized in Table 1.

Table 1. Frequencies of pre- and postnominal possessives, CREA corpus

\begin{tabular}{|l|l|l|l|l|}
\hline \multirow{2}{*}{} & \multicolumn{2}{|l|}{ Singular forms } & \multicolumn{2}{l|}{ Plural forms } \\
\cline { 2 - 5 } & Prenominal & Postnominal & Prenominal & Postnominal \\
\hline $1^{\text {st }}$ person & $5,877(93 \%)$ & $445(7 \%)$ & $1,193(94.9 \%)$ & $64(5.1 \%)$ \\
\hline $2^{\text {nd }}$ person & $2,099(97.1 \%)$ & $62(2.9 \%)$ & $422(95.7 \%)$ & $19(4.3 \%)$ \\
\hline $3^{\text {rd }}$ person & $9,367(98.9 \%)$ & $105(1.1 \%)$ & $3,540(99.3 \%)$ & $24(0.7 \%)$ \\
\hline Total & $17,343(96.7 \%)$ & $592(3.3 \%)$ & $5,155(98 \%)$ & $107(2 \%)$ \\
\hline
\end{tabular}

There are two main differences between Norwegian and Spanish possessive structures: prenominal possessives are less frequent than postnominal ones in

\footnotetext{
${ }^{1}$ The search (both in the child and adult corpora) was limited to the forms mio 'mine', tuyo 'your', suyo 'his / her / its / their' for postnominal possessives and $m i$ 'my', $t u$ 'your' and $s u$ 'his / her / its / their' for the prenominal possessives, with all their inflectional variants. The forms nuestro 'our' and vuestro 'plural your' were not included. These forms are infrequent in oral texts (e.g. only 70 instances of vuestro in the oral texts in CREA), and they are the two only possessives with the same form in preand post-nominal position, which would have complicated the searches.
} 
Norwegian, while the opposite holds for Spanish, and the split in Spanish is sharper than in Norwegian, with $97 \%$ versus $3 \%$ and $25 \%$ versus $75 \%$. With respect to the first difference, we suspect that it is related to the facts discussed in the first section: with overt nouns, the informationally neutral order is a postnominal possessive in Norwegian and a prenominal possessive in Spanish. With respect to the second difference, there are plausible explanations as well. Recall that in Spanish, inside definite DPs, only third person postnominal possessives (with a contrastive reading) are allowed, while Norwegian allows any person in the prenominal position. Second, in Norwegian there are a few nouns that do not allow a postnominal possessive, largely because the relevant possessee cannot co-occur with the definite article (see Lødrup 2011, 2012), as illustrated in (9). In Spanish there are no nouns that cannot appear with a prenominal possessive.

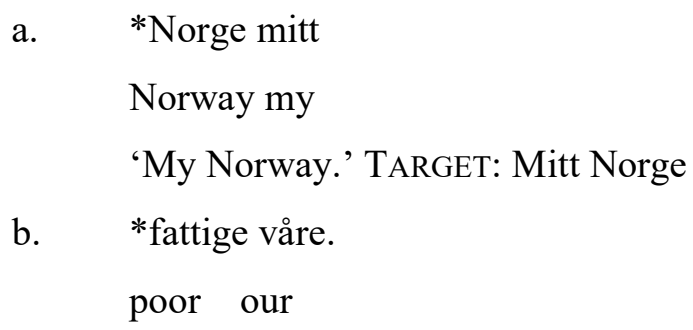

\subsection{Morphological differences}

In Norwegian, the prenominal and the postnominal possessives are morphologically identical, that is, they show exactly the same inflections in person, number and gender and agree with the possessee in both cases, here illustrated for the first and second person singular. ${ }^{2}$
a. $\quad\{\min / \operatorname{din} / \sin \} \quad$ bil my.M / your.M / his/her.M car.M
b. $\quad\{\mathrm{mi} / \mathrm{di} \quad / \mathrm{si}\} \quad$ bok
my.F / your.F/ his/her.F book.F

\footnotetext{
${ }^{2}$ There is one exception to the generalization that the possessive agrees with the possessee, found in the third person singular. There are two forms of third person singular possessors in Standard Norwegian: the reflexive ( $s i$, sin, sitt, sine 'his/her'), which agrees with the possessee, and the nonreflexive (hans, 'his', hennes 'her', dens / dets 'its'), which recovers the number and gender features of the possessor.
} 

c. $\quad\{$ mitt / ditt / sitt $\}$ hus
my.N / your.N / his/her.N house.n
d. $\quad$ mine / dine / sine $\} \quad$ biler
my.PL / your.PL / his/her.Pl car.m.PL

$\begin{aligned} \text { (11) a. } & \text { bil-en }\{\min / \operatorname{din} / \sin \} \\ & \text { car-DEF my.M / your.M / his/her.M } \\ \text { b. } & \text { bok-a }\{\mathrm{mi} / \mathrm{di} / \mathrm{si}\} \\ & \text { book-DEF my.F / your.F / his/her.F } \\ \text { c. } & \text { hus-et }\{\mathrm{mitt} / \mathrm{ditt} / \mathrm{sitt}\} \\ & \text { house-DEF my.N / your.N / his/her.N } \\ \text { d. } & \text { bilene }\{\text { mine / dine / sine }\} \\ & \text { car-PL-DEF my.PL / your.PL / his/her.PL }\end{aligned}$

In contrast, the two word orders in Spanish are matched by morphological differences. Prenominal possessives inflect for number, but not for gender (with the exception of the $1^{\text {st }}$ and $2^{\text {nd }}$ person plural forms), while postnominal possessors always inflect for number and gender, illustrated in (12) and (13).
a. $\{\mathrm{mi} / \mathrm{tu} / \mathrm{su}\} \quad$ libro
my / your / his.her.their book.M
b. $\quad\{\mathrm{mi} / \mathrm{tu} / \mathrm{su}\} \quad$ casa
my / your/ his.her.their house.F
c. $\{$ mis / tus / sus $\} \quad$ libros / casas
my.PL/your.PL/his.her.their.PL book.M.PL house.F.PL
(13) a. un libro \{mí-o / tuy-o / suy-o $\}$
a book.M my-m/your-m/ his.her.their-M
b. una casa $\{$ mí-a / tuy-a / suy-a
a house.F my-F/your-F/ his.her.their-F
c. libro-s \{mí-o-s / tuy-o-s / suy-o-s
book.M-PL my-M-PL your-M-PL his.her.their-M-PL


The following list summarizes the main empirical differences for the possessives in adult Norwegian and Spanish:

- In Norwegian, the prenominal / postnominal contrast is associated with information structure; in Spanish, definiteness and the person information of the possessive are more important

- In Norwegian, the informationally neutral order involves a postnominal possessive; in Spanish, only the postnominal possessive can be associated with focus

- In Norwegian, postnominal possessives are more frequent; in Spanish, prenominal possessives are more frequent

- In Norwegian, there are no morphological differences between prenominal and postnominal possessives; in Spanish, postnominal possessives contain gender information that prenominal possessives lack

\subsection{Analysis in the adult language}

With this background in mind, let us see how the two orders have been analysed in each language. The syntactic structure of Norwegian DPs has been extensively studied (Taraldsen 1990, Delsing 1993, Kester 1993, 1996, Santelmann 1993, Svenonius 1994, Vangsnes 1999, Julien 2002, 2005, Anderssen 2006, 2007, 2012, Roehrs 2009, Simonenko 2011 inter alia). One reason for this is that it is relatively complex. For example, modified definite noun phrases include two definiteness markers (14b), while unmodified phrases only involve one, the suffixal article (14a), which also co-occurs with postnominal possessives (cf. example (2)).
(14) a. hus-et
house-DEF
'The house.'
b. det gamle hus-et
the old house-DEF
'The old house.'


As a result, there is no generally agreed upon analysis of all aspects of Norwegian DPs. However, the very thorough exposition provided in Julien (2005) is close to a standard approach. Also, there are certain assumptions that are shared by most analyses. One of these is the idea that there are two determiner positions in Norwegian, one above and one below the adjective phrase (referred to as $\alpha$-phrase in Julien 2005). This proposal originates in Taraldsen (1990). The suffixal article occurs in the lower of the two positions. Another common assumption is that both the preand the postnominal possessives originate in the same position above the head noun but below the position of the suffixal article. In postnominal possessives, the noun moves across the possessor to merge with the suffixal article, while, in prenominal possessives, the possessive moves to a higher position in the DP, most likely the specifier position. One reason for this is that some varieties of Scandinavian allow the co-occurrence of prenominal possessives and the prenominal definite article, and in these cases, the word order is possessive - determiner-adjective - noun (- suffixal article), with the order determiner-possessive - adjective -noun being ungrammatical (cf. Vangnes 1999: 153, 156, for the Swedish dialects Lappträsk and Karleby, and Julien 2005: 197, for Danish):
a. mett te stór hús-e (Lappträsk)
my the big house-the
b. mín he grann hest-e
(Karleby)
my the nice horse-the
c. min den sorte kat
(Danish)
my the black cat

This results in the following structural difference between the two possessive structures (along the lines proposed by Julien 2005), both meaning 'my big car': 3

\footnotetext{
${ }^{3}$ The two determiner phrases are referred to here as DP1 and DP2 for simplicity, and the use of these names carry no significance. Various different labels have been used to refer to the lower position by other authors, such as DxP (Definite suffix Phrase, Vangsnes 1999) and nP (Julien 2005).
} 
(16)

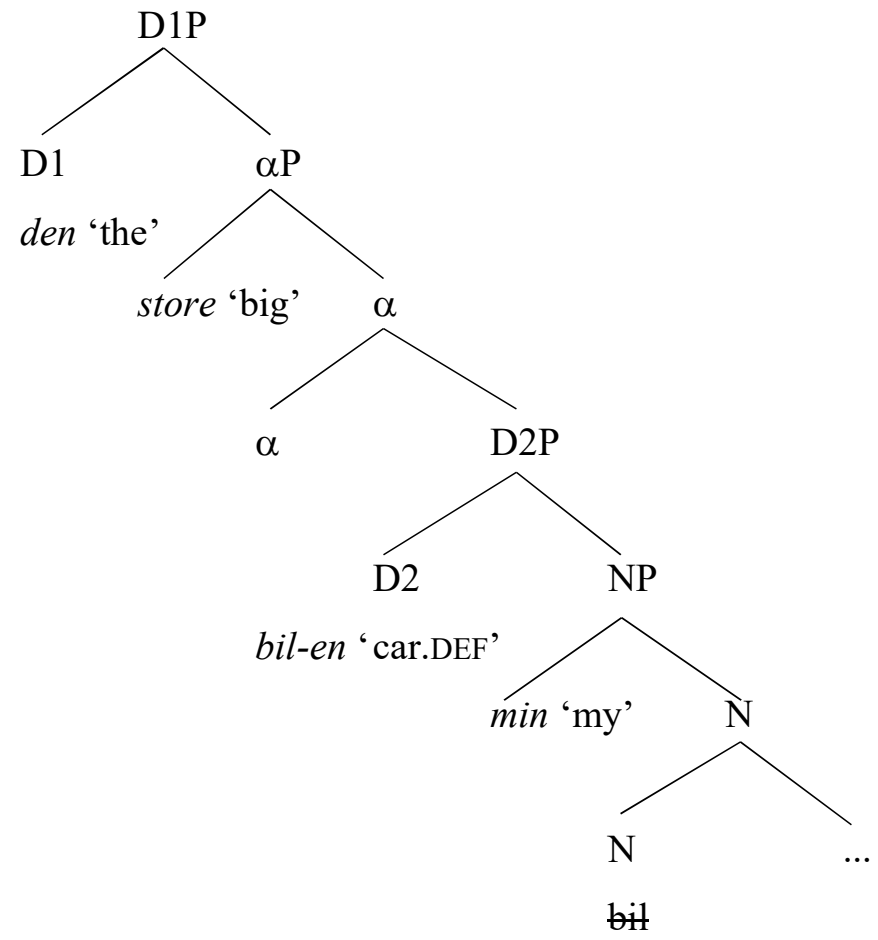

(17)

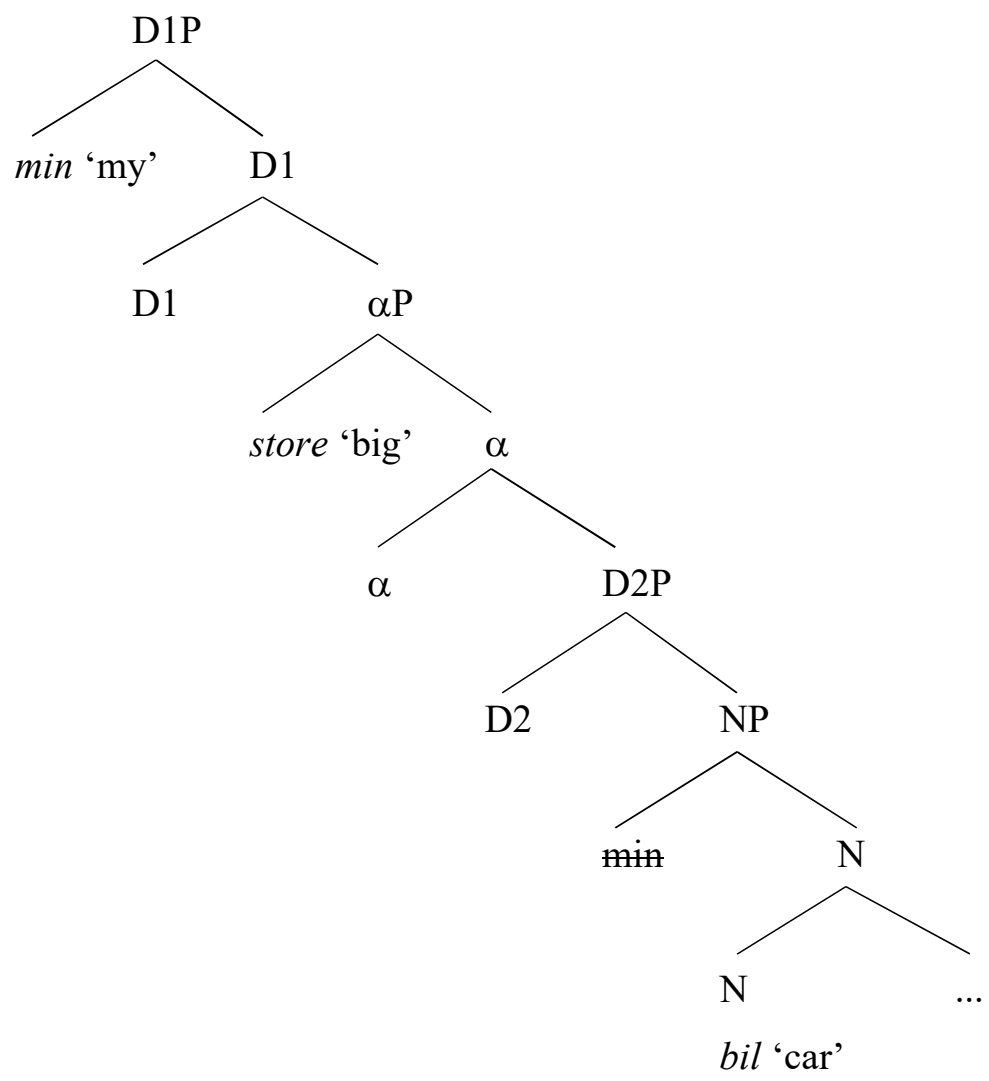


According to Julien (2005) the prenominal possessive moves because it is attracted to a focus feature, reflecting the fact that these structures tend to be contrastively focused. ${ }^{4}$

For Spanish the consensus is that the distinction in ordering involves movement of the postnominal possessive to the D layer (Brucart 1994, Ihsane 2003, Eguren 2015). Ignoring technical differences, the postnominal ordering (for instance with an indefinite DP) is the result of the possessive not being attracted to the DP layer and the noun moving to an inflectional head (gender or number), illustrated in (18). The prenominal ordering in (19) involves the possessive being attracted to DP.

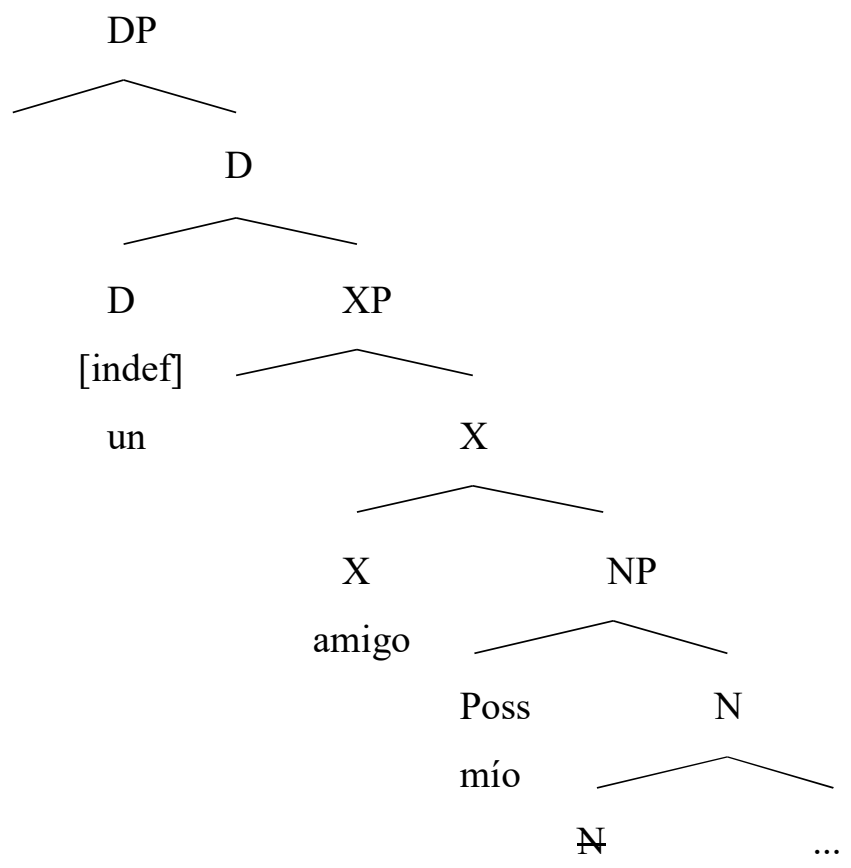

\footnotetext{
${ }^{4}$ Note that Julien posits a PossP immediately dominanted by DP, and it is this projection that carries the focus feature that attracts prenominal possessives. However, as the possessive is always subsequently attracted to the DP, we have not included the PossP here for reasons of simplicity.
} 
(19)

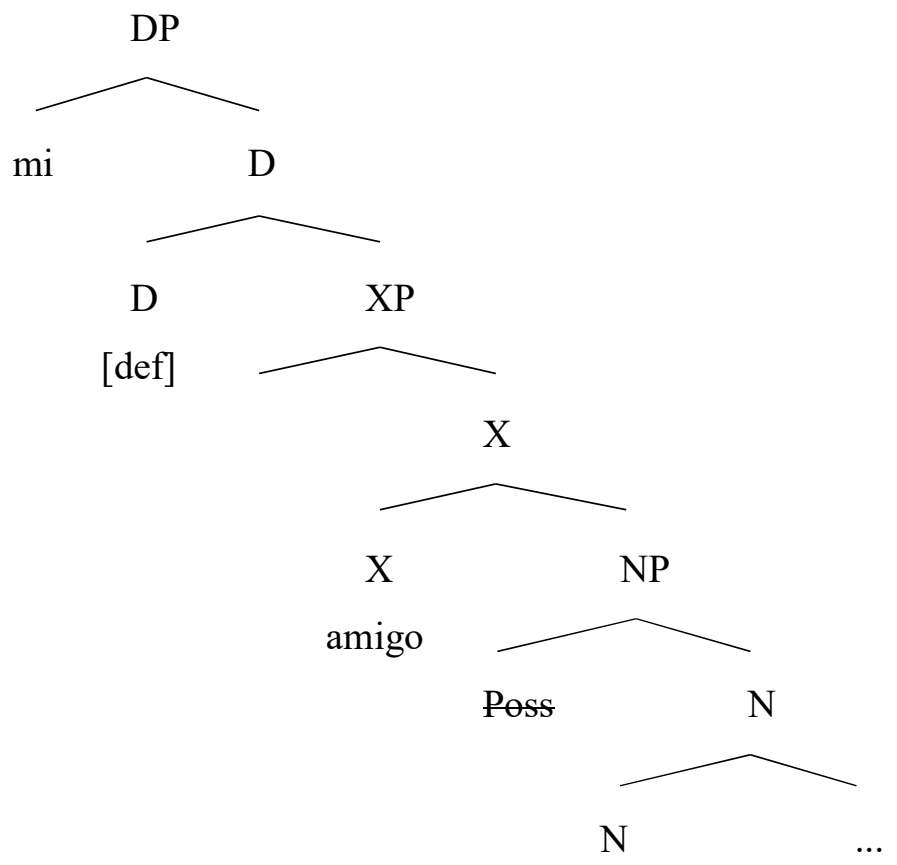

Movement of the possessive to DP in Norwegian does not depend on the features of the possessive, but this is the case in Spanish. In Norwegian this movement is related to a focus interpretation, but in Spanish it is a matter of feature checking in definite contexts. For this reason, Norwegian prenominal possessives are contrastive, and Spanish prenominal possessives are not. The postnominal possessive in Spanish can get a contrastive reading, which is a result of the Nuclear Stress Rule (Cinque 1993), which assigns nuclear stress to the lowest overt element in a domain (in (18), the possessive). Stress shift is also possible in Norwegian possessives, as a postnominal possessor may receive prosodic prominence, accompanied by the expected contrastively focused interpretation (see e.g. Lødrup 2011, 2012), as illustrated in (20) (from Lødrup 2011: 386).

(20) Først ble bilen MIN stjålet, og nå er bilen DIN stjålet. first was car.DEF my stolen and now is car.DEF your stolen 'First MY car was stolen, and now YOURS has been stolen.'

In Spanish, given the morphological differences between prenominal and postnominal possessives (which Norwegian lacks), the postnominal possessive is spelled out as a stress bearing unit, while the prenominal possessive is always unstressed. For this 
reason, the form of the postnominal possessive is the one used in ellipsis contexts, where $\mathrm{N}$ is empty:

$$
\begin{aligned}
& \text { tu libro y ese } \_\{\text {mío } / * \text { mi }\} \\
& \text { your book and that } \text { my }^{\text {post }} / \mathrm{my}^{\text {pre }} \\
& \text { 'Your book and mine.' }
\end{aligned}
$$

With this background, let us move to the study of possessives in Spanish child language.

\section{The acquisition of possessives in Spanish in contrast to Norwegian}

\subsection{The child data}

In order to investigate the acquisition of possessive structures in Spanish, we examined the following longitudinal corpora in CHILDES (Child Language Data Exchange System, MacWhinney 2000). The relevant information about the corpora is summarized in Table 2.

Table 2: Overview of Spanish child data investigated.

\begin{tabular}{|l|l|l|}
\hline NAME (sex) /Files & AGE RANGE & $\begin{array}{l}\text { NO. OF CHILD } \\
\text { UTTERANCES }\end{array}$ \\
\hline $\begin{array}{l}\text { Magín (M) } \\
\text { (Aguirre 2000) }\end{array}$ & $1 ; 7-2 ; 7$ & 10,921 \\
\hline $\begin{array}{l}\text { Irene (F) } \\
\text { (Llinás-Grau \& Ojea 2000) }\end{array}$ & $0 ; 11-3 ; 2$ & 11,907 \\
\hline $\begin{array}{l}\text { Juan (M) } \\
\text { (Linaza et al. 1981) }\end{array}$ & $2-4$ & 2,518 \\
\hline $\begin{array}{l}\text { Mendía (F) } \\
\text { (Nieva 2013) }\end{array}$ & $1 ; 8-2 ; 3$ & 14,230 \\
\hline $\begin{array}{l}\text { Juan (M) } \\
\text { (Aguado-Orea \& Pine 2015) }\end{array}$ & $1 ; 10-2 ; 7$ & 9,923 \\
\hline $\begin{array}{l}\text { Lucía (F) } \\
\text { (Aguado-Orea \& Pine 2015) }\end{array}$ & $2 ; 2-2 ; 7$ & 16,488 \\
\hline
\end{tabular}


The criteria used to select these files were (i) that the study was longitudinal, in order to allow us to see possible development of the relevant forms; (ii) that the children spoke a European variety of Spanish, and (iii) that, to the best of our knowledge, the children were monolingual. Even though the Spanish child corpora investigated here involve as many as 65,987 child utterances, the corpus search only yielded a total of 536 relevant utterances containing possessives (corresponding numbers from the Norwegian corpus investigated in Anderssen \& Westergaard (2010) are 449 examples of possessives out of a total of 46,685 child utterances). Thus, it is important to be aware that our results are based on a limited amount of data, and any conclusions need to be drawn with a certain degree of caution.

For comparison, let us first outline the findings from the Norwegian child data investigated in Anderssen \& Westergaard (2010): The three children in the corpus produced very few relevant examples at an early stage (Stage 1, age 1;9-2;0), in fact only 7 possessives were attested, all of them prenominal, despite this word order being the less frequent one in the input (approx. 25\%, see above). Postnominal possesssives appear in the data of all three children soon after the age of 2 , but until age 2;4 (Stage 2), prenominal possessives can be said to be overused $(47 \%, 21 / 45)$. During stage 3 (age 2;4-2;8), the distribution of the two word orders begins to correspond to the percentages in the adult data, $19 \%(21 / 108)$.

The results of the Spanish corpus searches reveal that the children start out with both word orders, and normally -with two exceptions- use the prenominal possessive first. As expected, the children also exhibit a predominance of prenominal possessives. Recall that in the adult spoken corpus, this word order represents $97 \%$ of all possessives. Interestingly, the predominance of these structures is not as strong in child language. For the majority of the children (the three boys and Lucía), prenominals are used at $80-100 \%$. The same is true of the two remaining children (Irene and Mendía) after the age of two. However, between the ages of one and two, they produce only $67 \%$ and $17 \%$ prenominal possessives, respectively. Table 3 provides an overview of the number and proportion of prenominal and postnominal possessives for each of the six children. 
Table 3. Percentage and number of prenominal possessives in child language

\begin{tabular}{|c|c|c|c|c|c|c|}
\hline & Magín & Irene & Juan & Mendía & Juan & Lucía \\
\hline $0-1$ & NO FILES & NO DATA & NO FILES & NO FILES & NO FILES & NO FILES \\
\hline $1-2$ & $\begin{array}{c}81 \% \\
(13 / 16)\end{array}$ & $\begin{array}{l}67 \% \\
(4 / 6)\end{array}$ & NO FILES & $\begin{array}{l}17 \% \\
(1 / 6)\end{array}$ & NO DATA & NO FILES \\
\hline $2-3$ & $\begin{array}{c}91 \% \\
(180 / 197)\end{array}$ & $\begin{array}{c}92 \% \\
(84 / 91)\end{array}$ & $\begin{array}{l}100 \% \\
(5 / 5)\end{array}$ & $\begin{array}{l}88 \% \\
(7 / 8)\end{array}$ & $\begin{array}{c}97 \% \\
(75 / 77)\end{array}$ & $\begin{array}{c}98 \% \\
(113 / 115)\end{array}$ \\
\hline $3-4$ & NO FILES & NO DATA & $\begin{array}{l}100 \% \\
(11 / 11)\end{array}$ & NO FILES & NO FILES & NO FILES \\
\hline+4 & NO FILES & NO FILES & $\begin{array}{l}50 \% \\
(2 / 4)\end{array}$ & NO FILES & NO FILES & NO FILES \\
\hline Total & $\begin{array}{c}91 \% \\
(193 / 213)\end{array}$ & $\begin{array}{c}91 \% \\
(88 / 97)\end{array}$ & $\begin{array}{c}90 \% \\
(18 / 20)\end{array}$ & $\begin{array}{l}57 \% \\
(8 / 14)\end{array}$ & $\begin{array}{c}97 \% \\
(75 / 77)\end{array}$ & $\begin{array}{c}98 \% \\
(113 / 115)\end{array}$ \\
\hline $\begin{array}{l}\text { Age first } \\
\text { prenominal }\end{array}$ & $1 ; 8.15$ & $1 ; 8.09$ & $2 ; 4.08$ & $1 ; 11.23$ & $2 ; 0.09$ & $2 ; 2.25$ \\
\hline $\begin{array}{l}\text { Age first } \\
\text { postnominal }\end{array}$ & $1 ; 10.27$ & $1 ; 8.09$ & $2 ; 3$ & $1 ; 11.06$ & $2 ; 1.18$ & $2 ; 3.24$ \\
\hline
\end{tabular}

Thus, even though there are relatively few relevant examples, especially in the early files of the children, they seem to be sensitive to the distinction between the two word orders, in that the frequencies are similar to the proportions found in the adult corpus. The children provide target-consistent examples of both word orders, illustrated in (22) and (23).

(22) FAT: mira donde está la pelota look where is the ball

FAT: $\quad$ toma nene . take, child [here you have, son]

CHI: $\quad$ mi polota [: pelota]. (Magín, 1;8.15) my ball

(23) CHI: un botón.

a button 


$\begin{array}{lll}\text { MOT: } & \text { pero bueno. } \\ & \text { but well [but come on!] } & \\ \text { CHI: } & \text { y un botón mío. } & \text { (Magín, 1;11.20) } \\ & \text { and a button my } & \\ \text { MOT: } & \text { www . } \\ \text { CHI: } & \text { se ha caído botón . } \\ & \text { SE has fallen button }\end{array}$

However, the children produce two types of non-target-like structures, (i) overuse of the least frequent form, the postnominal possessives, and (ii) doubling, i.e. the use of both the prenominal and the postnominal possessives in the DP. This latter type is only attested for one of the children, Magín. Let us consider these in turn.

\subsection{Postnominal possessives used in non-target-like environments}

The first type of non-target-consistent utterance is illustrated in (24)-(28), where a postnominal possessive combines with a definite NP, something that is ungrammatical in the adult language: Such cases show the use of the postnominal possessive in a context where the adult grammar does not allow them, illustrated in (7a-b), i.e. */?? $\mathrm{D}^{\text {def }} \mathrm{N}$ Poss ${ }^{1 \mathrm{st} / 2 \mathrm{nd}}$. Numerically, there are very few cases of this nontarget-consistent use of the postnominal possessive in the child data: 10 in total $(1,87 \%)$, which involve three produced by Magín, one by Irene, and two each by Lucía and the two boys named Juan. This type of error cannot be explained as a frequency effect: as we have seen, in adult Spanish, prenominal possessives are much more frequent than postnominal ones.

(24) FAM: ah, decías la habitación. ah, you.mean the room

CHI: $\quad$ me lo quitas la habitación mía ? (Magín, 2;3.10) from.me it you.remove the room my? 'Do you take my room?'

$\begin{array}{ll}\text { CHI: } & \text { se ha estropea(d)o el bolso mío. } \\ & \text { SE has broken the bag my } \\ \text { MOT: } & \text { se ha estropea(d)o el bolso ? }\end{array}$


SE has broken the bag?

CHI: mío.

mine

(26) MOT: por_qué?

why?

CHI: $\quad$ porque $[x$ 3] quiero la tirita mía. (Magín, 2;4.25)

because I.want the plaster my

MOT: $\quad$ porque quieres la tirita ?

because you.want the plaster?

CHI: mía!

my!

(27) CHI: me das tú, Papá .

me give you, Dad.

FAT: $\quad \&=$ q el qué ?

what?

CHI: el pan mío .

(Lucía, 2;6.14)

the bread my

(28) CHI: $\quad$ las botas de agua tuyas, las rojas . (Juan [Linaza], 4;8.12)

the boots of water your, the red.PL

'The water boots of yours, the red ones.'

Despite the low frequency, this production is still revealing because, crucially, these non-target-consistent utterances always go in the same direction: showing inappropriate use of the postnominal possessive. It would be logically possible for the children to produce non-target consistent structures where the prenominal possessive is overused, e.g. in an indefinite noun phrase, such as in (29). However, a manual examination of the data did not provide a single instance of such cases.

*mi amigo de la clase (unattested)

my friend of the class

Intended: 'a friend of mine from the classroom' 
Anderssen \& Westergaard (2010) observe that there are a number of clear cases of overuse of the prenominal possessive in Norwegian child language; that is, the use of this word order in non-contrastive contexts; see (30). Thus, in both languages, it is the least frequent word order that is overused.

(30) INV: ja eg ser det kjem opp igjennom sugerøret.

yes I see it come up through straw.DEF

'Yes, I can see it coming up through the straw.'

CHI: i min munn.

(Ina.20; age 2;8.27, stage 4)

in my mouth

'Into my mouth.']

INV: ja og opp i munnen din.

yes and up in mouth.DEF your

'And into your mouth, yes.'

\subsection{Double possessives}

In addition to the above examples, we also find some cases of possessive doubling, where both a prenominal and a postnominal possessive form are found inside the same DP. All these are non-target-consistent; to the best of our knowledge, they are invariably ungrammatical in all varieties of Spanish. There are four such cases altogether, all produced by Magín, illustrated in (31)-(33). Note that the child corrects himself in (31).

CHI: $\quad$ no está.

not it is.

'It is not here.'

MOT: $\quad$ el qué ?

what?

CHI: $\quad$ mi patio mío.

(Magín, 2;4.10)

my yard my

CHI: $\quad$ mi patio .

my yard 
CHI: en mi casa mía .

(Magín, 2;6.10)

in my house my

FAM: $\quad$ hay que buscar una hoja, pero esto que está aquí no . we must look.for a paper, but this that is here not.

$\mathrm{CHI}$ mío, 0 pintar [*] mi hoja mía.

(Magín, 2;10.24)

mine, paint my paper my

These examples are all cases where the DP is definite, so the expected form is the prenominal possessive. Thus, non-target-consistent forms produced by the Spanish children always involve overuse of the postnominal possessive.

\section{Discussion}

What we have seen in the child data is that, in both Spanish and Norwegian, children display non-target-like utterances involving the less frequent order: in Spanish this implies using the postnominal possessive in contexts where it is not grammatical, and in Norwegian the prenominal possessive is overused.

In what follows, we consider two possible explanations of the patterns found in child Spanish and child Norwegian. The first one - suggested by an anonymous reviewer is that the attested difference is related to Cardinaletti \& Starke's (1999) distinction between clitics, weak pronouns and strong pronouns. According to such an account, examples of overuse of the postnominal order in Spanish and the prenominal one in Norwegian could either be due to the children treating the weak or clitic form of the pronoun as marked (in accordance with cross-linguistic tendencies, cf. Bresnan 2001) and thus avoiding it, or alternatively that they have a greater preference for the strong and more salient pronominal forms (these two alternatives represent the flip side of each other, and cannot really be distinguished). The second possibility follows Anderssen \& Westergaard's (2010) complexity approach. According to the analysis of the adult structures in the two languages (cf. section 2.4), the prenominal ordering in Spanish involves movement of the possessive from the postnominal position, while in Norwegian the postnominal ordering involves movement of the noun over the 
possessive. In both cases children's non-target-consistent utterances represent an overuse of structures that do not involve movement.

Let us begin with an account that is related to the nature/complexity of the possessives in Spanish and Norwegian as strong pronouns, weak pronouns or clitics, following Cardinaletti \& Starke (1999). The difference between the three pronouns is syntactic and structural, in the sense that they can be ordered by their increasing structural complexity, with the strong pronoun involving layers not present in weak pronouns, and these again including layers not contained in the clitic.

According to this division, the postnominal possessive in Spanish is a weak pronoun, while the prenominal forms $m i, t u$ and $s u$ are clitics. Note first of all that this view has a potential way of accounting for why mio shows gender agreement and $m i$ does not, as the former would contain additional structural layers (but see below for a problem with this). From this perspective, the non-target-like cases in Spanish child language always display overuse of the pronominal form (the postnominal possessive). This would imply that Spanish children, at these early stages, have a preference for a more complex structure in possessives, possibly due to its salience or the fact this long form is also the one that is used in isolation (thus it appears in child language earlier than possessive/noun combinations). This could also be seen as avoidance of clitics in early child language: clitics have often been shown to be omitted or replaced by DPs in L1 acquisition (Hamann, Rizzi \& Freuenfelder 1995, Jakubowicz et al. 1996). For young children, using the pronominal alternative for possessives might be another way of dealing with this difficulty.

A piece of data potentially supporting this approach is that there are cases where children seem to use mio as a pronominal form in non-possessive contexts. One child that produces the relevant non-target-like utterances, Magín, also uses the long form of the possessive as a pronominal in contexts where $m i$ ' $m e$ ' would be expected, i.e. after a preposition, illustrated in (34). Magín produces five structures like this at age $1 ; 10$ (and only one more later, at 2;3.10).

$\mathrm{CHI}$

para mío .

(Magín, 1;10.15)

for my 
An analysis along these lines has also been proposed for Norwegian by Lødrup (2011), who argues that the prenominal possessive is a strong pronoun while the postnominal is weak, alternatively clitic- or even suffix-like (since no element may intervene between the noun and the postnominal possessive). In terms of interpretation, prenominal possessives are typically focused, on a par with strong pronouns generally, while postnominal pronouns are usually topical, which is what would be expected of weak pronouns. However, these elements do not exhibit the typical behavior with regard to placement in Norwegian, with the focal possessive pronoun occurring towards the beginning and the topical possessive appearing towards the end of the phrase. Nevertheless, Lødrup (2011: 385-388) argues convincingly that the strong/weak distinction can be attributed to pre- and postnominal possessives in Norwegian. Following this line of argument, one possible analysis of Norwegian child language would be that the overuse of the prenominal possessive is the result of a preference for the unmarked and more salient option, that is, strong pronouns over weak ones (for arguments that the former is unmarked, see Lødrup 2011, 2012). Note that this explanation along the strong/weak pronoun dichotomy in Norwegian is not in direct competition with the structural/economy approach discussed above.

However, an account in terms of the nature/complexity of the possessives faces some problems, both on theoretical and empirical grounds. First, it is not obvious that the presence of gender marking in the postnominal possessive in Spanish should be directly related to the structural complexity approach of Cardinaletti \& Starke (1999). The reason is that if we look outside possessives, the contrast between clitic (35a), weak pronoun (35b) and strong pronoun (35c) in first and second person forms does not involve gender marking at any point. The presence of gender marking in postnominal forms is thus unexplained by this account.
a. me (clitic) 'me'
b. mí (weak pronoun) 'me'
c. a mí (strong pronoun) '(to) me' 
Second, the status of the postnominal possessive in Norwegian is controversial, and there are relatively clear arguments that it cannot be a clitic: it allows ellipsis of its host, as in (36). Thus, Lødrup (2011: 390) uses the term 'weak' "to stress the grammatical (as opposed to phonological) nature of the difference between prenominal and postnominal possessives."

Vil hun ha den røde kjolen min, eller den blåe $\operatorname{din} ?$ will she have the red dress.DEF my or the blue your 'Does she want my red dress or your blue one?'

Finally, and perhaps most importantly, not all acquisition evidence indicates that clitics or clitic-like elements are acquired late, as clitics have been shown to be omitted much less frequently in languages such as Spanish and Greek than in French and Italian (Schaeffer 2000, Wexler, Gavarró \& Torrens 2004, Tsakali \& Wexler 2004). There may also be support for this in our current child data.

In Norwegian, the postnominal possessive involves the suffixal form of the definite determiner, which is normally considered to be an affix (see e.g. Faarlund 2009 for Norwegian and Börjars 1998 for Swedish), but it has also been argued to be clitic-like (see e.g. Lahiri, Wetterlin \& Jönsson-Steiner 2005). Thus, the early preference for the prenominal possessive could be due to an avoidance of the definite suffix (as suggested to us by an anonymous reviewer). However, the suffixal article is acquired very early, typically before or around the age of two, and it is therefore unlikely to be the source of the overuse of the postnominal possessive at a later stage of development (Anderssen 2007, 2010, 2012). Furthermore, it should be noted that the overuse of the postnominal possessive construction in Spanish also involves an element that is standardly argued to be a clitic (according to e.g. Leonetti 1999), the prenominal definite article (cf. examples (24)-(28) above). This means that it is highly unlikely that Spanish children overuse the postnominal possessive construction (which includes a clitic) because they want to avoid producing a possessive clitic in prenominal position. It has also been shown in numerous studies (e.g. Lleó 2001) that the enclitic definite article is acquired very early in Spanish — long before the corresponding articles in Germanic languages. Finally, the prenominal possessive also seems to be acquired earlier than the postnominal one for most of the Spanish children 
in this study (cf. Table 3), suggesting that this form is not in principle problematic in first language acquisition and does not constitute the children's initial choice.

We now move on to considering the economy of movement account. Recall from the description given in section 2.4 that the standard analysis for Spanish (since Brucart 1994) is that the prenominal ordering is obtained from the derivationally simpler postnominal ordering by moving the possessive to the DP projection. In Norwegian this movement is also proposed for adult language, but crucially note that Norwegian - unlike Spanish - has double definiteness, and as a result of this, there is a projection below the adjectival projection for the suffixal determiner, illustrated in (37):

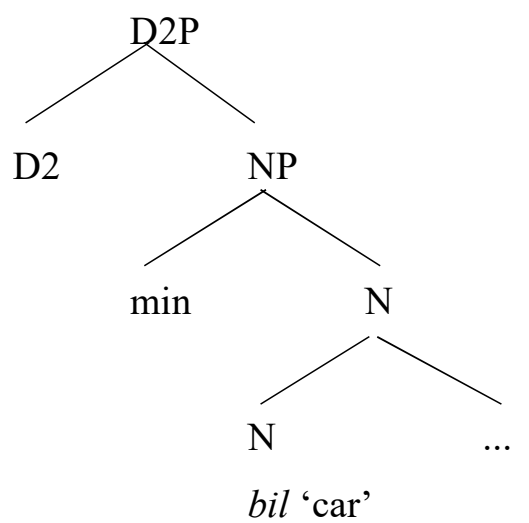

Both possessive orders could be generated within this structure. The prenominal possessive would not involve any syntactic movement, but represent the basic word order in the DP, and the postnominal ordering would involve movement of N to D2. There are a number of proposals arguing that early child language does not have the complete adult structure in place, either due to maturation (e.g. Borer \& Wexler 1987, 1992, Radford 1990), truncation of structure (e.g. Rizzi 1993, Haegeman 1996), or weak continuity structure-building approaches such as Clahsen, Penke \& Parodi (1993), Clahsen, Eissenbeiss \& Penke (1996), Radford (1996), Duffield (2008), Westergaard (2009). Under all these approaches, early stages of Norwegian child language could be argued to have a smaller structure available than the full-fledged adult Norwegian structure with two D heads. If so, the prenominal possessive could be generated without any syntactic movement. Such an analysis might survive in the child grammar until the child starts producing modified definites (involving the projection of the adjective and later also the prenominal determiner), which appear 
later in Norwegian child language (Anderssen 2006, 2007). It has been argued that economy in child language involves two phenomena: not building more structure and not moving elements higher in the structure than there is evidence for in the input (e.g. Westergaard \& Bentzen 2007, Westergaard 2009). We here propose that children, when possible, avoid movement.

On this view, the non-target-like utterances of both Norwegian and Spanish children would involve structures that avoid syntactic movement. Note, however, that syntactic movement is not generally problematic for children. Numerous studies have shown that children apply various types of syntactic movement early on (e.g. Poeppel \& Wexler 1993, Wexler 1998). This has also been extensively shown for various word order phenomena in Norwegian (e.g. Westergaard 2009, 2014), including Nmovement to the lower of the two determiner positions in simple definite DPs (Anderssen 2007, 2010, 2012). Also for possessive structures, Norwegian children are adult-like already around the age of 2;6-2;8. Nevertheless, there are also several studies showing that, in some contexts, typically in situations where there are two possible word orders and the choice between them is dependent on interpretation and/or information structure, syntactic movement is not consistently applied at the earliest stage (Schaeffer 2000, Unsworth 2005, Westergaard 2011, 2014, Anderssen, Bentzen, Rodina \& Westergaard 2010, Mykhaylyk \& Ko 2010, Anderssen, Bentzen \& Rodina 2012, Mykhaylyk, Rodina \& Anderssen 2013, Anderssen, Rodina, Mykhaylyk \& Fikkert 2014). In such cases, there is a tendency for movement to be avoided, possibly because of the cognitive load involved in determining which interpretation is appropriate and which copy to spell out. Possessives seem to be just such a case; the children apply syntactic movement from early on (at least from the age of two), but fail to consistently apply it in appropriate contexts. In situations such as these, children typically err on the side of caution, and move too little rather than too much, since overuse of movement is virtually unattested. This approach is in line with other theories arguing for economy or conservativeness in child language, often accounting for omissions (e.g. Snyder 2007, Phillips 2010).

On this account, we have to be clear about in what sense a derivation involving movement is more complex than one without it. In current syntactic theory (e.g. Chomsky 2013), movement has no special status as a syntactic operation: it is an 
instance of (internal) merge. At the stage, Norwegian and Spanish children are producing the non-target-consistent word orders, they obviously do not have a problem with merge, as they can build syntactic structure. However, movement involves an additional operation at PF: the speaker has to keep track of the two copies of the moved element, calculate the c-command relation between them and make one silent at PF. This is what would make movement operations more complex for children; i.e. not movement per se, but the treatment of copies at PF. That this is problematic for Spanish children is supported by the fact that double possessive structures are attested, where both the lower and the higher copy are spelled out (cf. examples 31-33 above). Thus, while children are clearly able to produce structures involving movement, some residual problems may remain, probably due to difficulties related to associating the correct interpretation with the spellout of the correct copy (increased complexity at PF).

However, this economy of movement approach is problematic from other perspectives. An anonymous reviewer points out that proponents of a strong continuity approach to language acquisition would generally find it problematic that this account assumes that children may project smaller syntactic structures than what is found in the adult language. Another reviewer notes that the morphological difference between pre- and postnominal possessives in Spanish would not be expected if they are the same element in two different positions. Indeed, given the standard analysis of the contrast in Spanish, the distinction between pairs of short and long forms such as mi / mio or tu / tuyo would have to be treated as morphophonological allomorphy, where the same set of features is spelled out as a reduced form when in the context of the DP-layer, and as a form with gender marking outside this context. An approach where each series of pronouns is different and not related to movement would avoid this problem, although it would have to explain why the two forms cannot co-occur. However, it is possible to imagine an approach where the differences in form are related to movement in the sense that only a subconstituent of the postnominal possessive moves to the higher position during the derivation; we will not develop this kind of analysis here.

Although empirically we believe that the movement-based approach is more promising, we see that neither approach to account for the child data is completely 
unproblematic. This suggests, to us, two things. First, it may be the case that the explanation should not be the same for the two languages, with the economy approach being more plausible for Norwegian, while the Spanish data could more convincingly be accounted for by assuming differences in the nature/complexity of the possessives themselves. Second, it may be necessary to combine these approaches in order to get a full picture. For instance, to the extent that clitics tend to involve prosodic restructuring effects at PF, young children may avoid certain structures with clitics because they increase complexity at PF precisely because of the syntactic movement operations they trigger to prosodically accommodate the clitic.

\section{Conclusion}

This paper discusses the acquisition of pre- and postnominal possessive structures in Spanish against the backdrop of a similar study of the acquisition of Norwegian possessives (Anderssen \& Westergaard 2010). For Norwegian, it has been shown that even though postnominal possessives are much more frequent in the input (75\%), children initially tend to overuse the prenominal possessives. This is argued to be due to prenominal possessives being less complex structures which can be produced without involving movement of the noun past the possessor. This is manifested in the overuse of prenominal possessives in inappropriate contexts. Spanish also allows both word orders, but there is a clear preference for prenominal possessives in adult Spanish (97\%). Not surprisingly, we find that Spanish children have the same preference as adults and produce mostly prenominal possessives. However, to the extent that Spanish children produce non-target-consistent structures, they overuse postnominal possessives, the considerably less frequent structure. In this paper, we have discussed two explanations for these findings, an economy of movement account (similar to what was argued in Anderssen \& Westergaard 2010 for Norwegian) and an account that considers the different nature/complexity of the possessives themselves in terms of strong/weak pronouns or clitics (Cardinaletti \& Starke 1999).

Both accounts explain why the postnominal possessive structure is overused in Spanish child data, while the prenominal one is the preferred word order in early child Norwegian. The economy of movement account explains instances of overuse in both languages as a result of occasional failure to carry out syntactic movement: movement of the noun across the possessive in Norwegian and movement of the possessive to 
the DP layer in Spanish (see section 2.4), relating this to numerous similar findings in early child language. Possible problems with this account involve theoretical issues such as strong continuity vs. structure building (the latter positing smaller structures in child language than in the adult language) or the question whether the two possessives in Spanish are related by movement or produced as two separate derivations. The second account, i.e. relating the difference between the two word orders to the nature/complexity of the possessives themselves, would argue that the prenominal possessive in Spanish and the postnominal possessive in Norwegian are lower in the complexity hierarchy of Cardinaletti \& Starke (1999), i.e. clitics or weak pronouns. The findings in child language could then be related to young children having a problem with clitics, alternatively a preference for the more salient form. However, this account also faces problems, both on theoretical and empirical grounds. Thus, neither account is totally satisfactory. In light of this and the differences between Spanish and Norwegian possessives, it might be that the child data have different explanations in the two languages - or that a combination of the two approaches may be necessary. For Spanish, the overuse of the postnominal possessive may be due to a combination of the clitic nature of the prenominal possessive and the fact that the postnominal possessive is more salient. This might even be exacerbated by the fact that the use of the clitic involves additional movement. For Norwegian, the acquisition data seem to be best accounted for in term of a movement approach, as proposed by Anderssen \& Westergaard (2010), possibly in combination with the strong versus weak pronoun account, as both accounts predict that the prenominal possessive should be overused.

\section{References}

Aguado-Orea, Javier \& Pine, Julián M. (2015). Comparing different models of the development of verb inflection in early child Spanish. PLOS ONE 10: e0119613. doi:10.1371/journal.pone.0119613

Aguirre, Carmen, (2000): La adquisición de las categorías gramaticales en español. Madrid: Ediciones de la Universidad Autónoma de Madrid.

Alexiadou, Artemis, Liliane Haegeman \& Melita Stavrou. 2007. Noun phrase in the generative perspective. Amsterdam: John Benjamins. 
Anderssen, Merete. 2006. The acquisition of compositional definiteness in Norwegian. Ph.D. dissertation, University of Tromsø.

Anderssen, Merete. 2007. The acquisition of compositional definiteness. In Merete Anderssen \& Marit Westergaard (eds.), Papers from the language acquisition workshop, SCL 2006, Nordlyd 34.3, 252-275.

Anderssen, Merete. 2012. A spanning approach to the acquisition of definiteness in Norwegian. Iberia: an international journal of theoretical linguistics 4, 1-34.

Anderssen, Merete \& Marit Westergaard. 2010. Frequency and economy in the acquisition of variable word order. Lingua 120.11, 2569-2588.

Anderssen, Merete, Kristine Bentzen, Yulia Rodina and Marit Westergaard. 2010. The acquisition of apparent optionality: The word order of subject- and object- shift constructions in Norwegian. In Merete Anderssen, Kristine Bentzen \& Marit Westergaard (eds.) Variation in the Input: Studies on the Acquisition of Word Order. [Studies in Theoretical Psycholinguistics 39], 240-270, Springer Verlag.

Anderssen, Merete, Kristine Bentzen \& Yulia Rodina. 2012. Topicality and complexity in the acquisition of Norwegian Object Shift. Language Acquisition 19.(1), 3972.

Anderssen, Merete, Yulia Rodina, Roksolana Mykhaylyk \& Paula Fikkert. 2014. The acquisition of the dative alternation in Norwegian. Language Acquisition, 21, 72-102.

Borer, Hagit \& Ken Wexler. 1987. The maturation of syntax. In Thomas Roeper \& Edwin Williams (eds.) Parameter setting, pp. 123-172. Springer Netherlands.

Borer, Hagit \& Ken Wexler. 1992. Bi-unique relations and the maturation of grammatical principles. Natural Language and Linguistic Theory, 10, 147-189.

Börjars, Kersti. 1998. Feature Distribution in Swedish Noun Phrases. Oxford: Blackwell.

Bresnan, Joan. 2001. The emergence of the unmarked pronoun. In Géraldine Legendre, Joan Grimshaw \& Sten Vikner (eds.), Optimality-theoretic syntax, pp. 113-142. Cambridge (Mass.): MIT Press.

Brucart, José M. 1994. Sobre una incompatibilidad entre posesivos y relativas especificativas. In Violeta Demonte (ed.), Gramática del español. México: Colegio de México, pp. 51-86. 
Cardinaletti, Anna \& Michal Starke. 1999. The typology of structural deficiency. A case study of the three classes of pronouns. In Henk van Riemsdijk (ed.), Clitics in the languages of Europe. Berlin: De Gruyter, pp. 145-233.

Chomsky, Noam. 2013. Problems of projection. Lingua 130, pp. 33-49.

Cinque, Guglielmo. 1993. A null theory of phrase and compound stress. Linguistic Inquiry 24, 239-297.

Clahsen, Harald, Martina Penke \& Teresa Parodi. 1993. Functional categories in early child German. Language acquisition 3, no. 4: 395-429.

Clahsen, Harald, Sonja Eisenbeiss, \& Martina Penke. 1996. Lexical Learning in Early Syntactic Development. In Harald Clahsen (Ed.), Generative Perspectives on Language Acquisition: Empirical findings, theoretical considerations and crosslinguistic comparisons (Vol. 14, pp. 129-159). Amsterdam: Benjamins.

Delsing, Lars-Olof. 1993. The internal structure of noun phrases in the Scandinavian languages, Ph.D. dissertation, University of Lund.

Duffield, Nigel. 2008. Roots and Rogues in German Child Language. Language Acquisition, 15(4), 225- 269.

Eguren, Luis. 1989. Algunos datos del español en favor de la frase determinante. Revista Argentina de Lingüística 5, pp. 163-203.

Eguren, Luis. 2015. Possessives and relative clauses in Spanish. Probus, to appear. Available as 'online first', https://www.degruyter.com/abstract/j/prbs.ahead-ofprint/probus-2015-0006/probus-2015-0006.xml

Faarlund, Jan Terje. 2009. On the history of definiteness marking in Scandinavian. Journal of Linguistics 45, 3, 617-639.

Haegeman, Liliane. 1996. Root infinitives, clitics and truncated structures. Language acquisition and language disorders 14, pp. 271-308.

Hamann, Cornelia, Luigi Rizzi \& Uli H. Frauenfelder. 1995. On the acquisition of subject and object clitics in French. In Celia Jakubowicz (ed.), Grammaire univeselle et acquisition du langage, Vincennes, France: Recherches Universitaires de Vincennes, 83-101.

Huerta Flores, Norohella. 2009. Los posesivos. In Concepción Company (ed.), Sintaxis histórica de la lengua española. La frase nominal. México: UNAM, pp. 609759. 
Ihsane, Tabea. 2003. A typology of possessive modifiers. In Martine Coene \& Yves D’Hulst (eds.), From NP to DP. Amsterdam: John Benjamins, 23-42.

Jakubowicz, Celia, Natascha Müller, Ok-Kyung Kang, Beate Riemer \& Catherine Rigaut. 1996. On the acquisition of pronominal system in French and German. In Andy Stringfellow, Dalia Cahana-Amitay, Elizabeth Hughes \& Andrea Zukowski (eds.), Proceedings of the 20th Boston annual University Conference on Language Development [BUCLD 20], Somerville, MA: Cascadilla Press, 374-385.

Julien, Marit. 2002. Determiners and word order in Scandinavian nominal phrases, Studia Linguistica 56.3, 265-315.

Julien, M., 2005. Nominal Phrases from a Scandinavian Perspective [Linguistics Today 87]. John Benjamins, Amsterdam.

Kayne, Richard. 1994. The antisymmetry of syntax. Cambridge (Mass.): MIT Press.

Kester, Ellen-Petra. 1993. The inflectional properties of Scandinavian adjectives, Studia Linguistica 47.2, 139-153.

Kester, Ellen-Petra. 1996. The nature of adjectival inflection, Ph.D. dissertation, OTS Dissertation Series, Utrecht.

Lahiri, Aditi, Allison Wetterlin and Elisabet Jönsson-Steiner. 2005. Lexical specification of tone in North Germanic. Nordic Journal of Linguistics 28, 1, 61-96.

Leonetti, Manuel. 1999. Los determinantes. Madrid: Arco Libros.

Linaza, José L., Sebastián, María E., \& del Barrio, Cristina. 1981. Lenguaje, comunicación y comprensión. La adquisición del lenguaje. Monografía de Infancia y Aprendizaje 1, 195-198.

Lleó, Conxita. 2001. The interface of phonology and syntax: The emergence of the article in the early acquisition of Spanish and German. Language acquisition and language disorders 24: 23-44.

Llinàs-Grau, Mireia \& Ana Ojea. 2000. Transcripts of corpus for Project BFF20000504 . 
Lødrup, Helge. 2011. Norwegian Possessive Pronouns: Phrases, Words or Suffixes? In Proceedings of the LFG11 Conference, ed. by Miriam Butt and Tracy Holloway King, 383-403. Stanford: CSLI Publications.

Lødrup, Helge. 2012. Forholdet mellom prenominale og postnominale possessive uttrykk. [The relationship between prenominal and postnominal possessive expressions]. In Grammatikk, bruk og norm [Grammar, Use and Norm], ed. by Hans-Olav Enger, Jan Terje Faarlund and Kjell Ivar Vannebo, 189-203. Oslo: Novus.

MacWhinney, Brian. 2000. The CHILDES Project: Tools for analyzing talk. Third Edition. Mahwah, NJ: Lawrence Erlbaum Associates.

Moreno de Alba, José G. 2001. El español en América. México: FCE.

Mykhaylyk, Roksolana and Heejeong Ko (this volume). Optional scrambling is not random: Evidence from Ukrainian acquisition. In Merete Anderssen, Kristine Bentzen \& Marit Westergaard (eds.) Variation in the Input: Studies on the Acquisition of Word Order. [Studies in Theoretical Psycholinguistics 39], 207239, Springer Verlag.

Mykhaylyk, Roksolana, Yulia Rodina \& Merete Anderssen. 2013. Ditransitive constructions in Russian and Ukrainian: The effect of givenness. Lingua 137, 271-289.

Nieva, Silvia. 2013. Función de la estructura del diálogo en la transición de una a dos palabras. Doctoral dissertation, Universidad Complutense de Madrid.

Parodi, Claudia. 1994. On case and agreement in Spanish and English DPs. In Michael L. Mazzola (ed.), Issues and Theory in Romance Linguistics. Washington: Georgetown University Press, pp. 403-416.

Phillips, Colin. 2010. Syntax at Age Two: Cross-Linguistic Differences. Language Acquisition, 17(1-2), 70-120.

Picallo, Carme \& Gemma Rigau. 1999. El posesivo y las relaciones posesivas. In Ignacio Bosque \& Violeta Demonte (eds.), Gramática descriptiva de la lengua española. Madrid: Espasa, pp. 973-1025.

Poeppel, David \& Kenneth Wexler. 1993. The full competence hypothesis of clause structure in early German. Language 1, 1-33.

RAE \& ASALE. 2009. Nueva gramática de la lengua española. Madrid: Espasa. 
Radford, Andrew. 1990. Syntactic theory and the acquisition of English syntax: The nature of early child grammars of English. Blackwell.

Radford, Andrew. 1996. Towards a structure-building model of acquisition. Language acquisition and language disorders 14, 43-90.

Rizzi, Luigi. 1993. Some notes on linguistic theory and language development: the case of root infinitives. Language Acquisition 3.4, 371-393.

Roca, Francesc. 2009. The left periphery of nominal constructions and the evolution of definite determiners in Romance. In Joan Rafel (ed.), Diachronic Linguistics. Girona: Documenta Universitaria, pp. 495-551.

Roehrs, Dorian. 2009. Demonstratives and definite articles as nominal auxiliaries. Linguistics Today 140. Amsterdam/Philadephia: John Benjamins.

Santelmann, Lynn. 1993. The Distribution of double determiners in Swedish: den support in $\mathrm{D}^{0}$, Studia Linguistica 47, 154-176.

Schaeffer Jeanette. 2000. The Acquisition of Direct Object Scrambling and Clitic Placement. Amsterdam/Philadelphia: John Benjamins.

Simonenko, Alexandra. 2011. Spellout and double determination in Mainland Scandinavian. University of Pennsylvania Working Papers in Linguistics 17, $205-214$.

Snyder, William. 2007. Child language: The parametric approach. Oxford University Press.

Svenonius, Peter. 1994. The structural location of the attributive adjective. The Proceedings of the Twelfth West Coast Conference of Formal Linguistics. 439454. Stanford, California: CSLI.

Taraldsen, Knut T. 1990. D-projections and N-projections in Norwegian. In Mascaró, Joan and Nespor, Marina (Eds.), Grammar in Progress. Foris, Dordrecht, pp. $419-431$.

Ticio, Emma. 2003. On the structure of DPs. $\mathrm{PhD}$ dissertation, University of Connecticut.

Tsakali Vina \& Kenneth Wexler. 2004. Why children omit clitics in some languages but not in others: new evidence from Greek. In Proceedings of GALA 2003, Utrecht University, pp. 493-504. 
Vangsnes, Øystein A. 1999. The identification of functional architecture. Doctoral dissertation. University of Bergen.

Unsworth, Sharon. 2005. Child L1, child L2 and adult L2 acquisition: Differences and similarities. A study on the acquisition of direct object scrambling in Dutch, Doctoral dissertation, Utrecht University.

Westergaard, Marit. 2009. The Acquisition of Word Order: Micro-cues, Information Structure and Economy. [Linguistik Aktuell/Linguistics Today 145], Amsterdam: John Benjamins.

Westergaard, Marit. 2014. Linguistic variation and micro-cues in first language acquisition. Linguistic Variation, 14.1, 26-45.

Westergaard, Marit. 2011. Subject positions and information structure: The effect of frequency on acquisition and change. Studia Linguistica 3, 299-332.

Westergaard, Marit \& Kristine Bentzen. 2007. The (non-) effect of input frequency on the acquisition of word order in Norwegian embedded clauses. In Insa Gülzow \& Natalia Gagarina (eds.), Frequency Effects in Language Acquisition: Defining the Limits of Frequency as an Explanatory Concept, [Studies on Language Acquisition], 271-306. Berlin/New York: Mouton de Gruyter.

Westergaard, Marit \& Merete Anderssen. 2015. Word Order Variation in Norwegian Possessive Constructions: Bilingual Acquisition and Attrition. In Janne Bondi Johannessen and Joe Salmons (eds.), Germanic heritage languages in North America: Acquisition, attrition and change [Studies in Language Variation], 2145. Amsterdam: John Benjamins.

Wexler, Kenneth. 1998. Very early parameter setting and the unique checking constraint: a new explanation of the optional infinitive stage. In Antonella Sorace, Caroline Heycock \& Richard Shillock (eds), Language Acquisition: Knowledge Representation and Processing, special issue of Lingua, 23-79. Amsterdam: Elsevier.

Wexler, Kenneth, Anna Gavarrò \& Vicent Torrens. 2004. Feature checking and object clitic omission in child Catalan and Spanish. In Reineke Bok-Bennema, Bart Hollebrandse, Brigitte Kampers-Manhe \& Petra Sleeman (eds.) Selected Papers from Going Romance 2002, [Current Issues in Linguistic Theory 256], pp. 253269. Amsterdam: John Benjamins. 